\title{
Fantasy proneness and thought suppresion as predictors of the Medical Student Syndrome
}

Citation for published version (APA):

Candel, I. E. L., \& Merckelbach, H. L. G. J. (2003). Fantasy proneness and thought suppresion as predictors of the Medical Student Syndrome. Personality and Individual Differences, 35, 519-524. https://doi.org/10.1016/S0191-8869(02)00214-3

Document status and date:

Published: 01/01/2003

DOI:

10.1016/S0191-8869(02)00214-3

Document Version:

Publisher's PDF, also known as Version of record

\section{Please check the document version of this publication:}

- A submitted manuscript is the version of the article upon submission and before peer-review. There can be important differences between the submitted version and the official published version of record.

People interested in the research are advised to contact the author for the final version of the publication, or visit the DOI to the publisher's website.

- The final author version and the galley proof are versions of the publication after peer review.

- The final published version features the final layout of the paper including the volume, issue and page numbers.

Link to publication

\footnotetext{
General rights rights.

- You may freely distribute the URL identifying the publication in the public portal. please follow below link for the End User Agreement:

www.umlib.nl/taverne-license

Take down policy

If you believe that this document breaches copyright please contact us at:

repository@maastrichtuniversity.nl

providing details and we will investigate your claim.
}

Copyright and moral rights for the publications made accessible in the public portal are retained by the authors and/or other copyright owners and it is a condition of accessing publications that users recognise and abide by the legal requirements associated with these

- Users may download and print one copy of any publication from the public portal for the purpose of private study or research.

- You may not further distribute the material or use it for any profit-making activity or commercial gain

If the publication is distributed under the terms of Article $25 \mathrm{fa}$ of the Dutch Copyright Act, indicated by the "Taverne" license above, 


\title{
Fantasy proneness and thought suppression as predictors of the Medical Student Syndrome
}

\author{
Ingrid Candel*, Harald Merckelbach \\ Department of Experimental Psychology, Maastrich University, PO Box 616, 6200 MD, Maastrich, The Netherlands
}

Received 7 February 2002; received in revised form 25 June 2002; accepted 23 July 2002

\begin{abstract}
This study examined individual differences correlates of the Medical Student Syndrome (MSS). A sample of 215 medical students completed a questionnaire measuring health complaints that had to do with their study as well as self-report scales tapping fantasy proneness, and habitual thought suppression attempts. Thirty percent $(n=65)$ of the respondents reported MSS complaints related to a wide variety of diseases. Fantasy proneness and thought suppression were found to be independent predictors of these complaints. (c) 2003 Elsevier Ltd. All rights reserved.
\end{abstract}

Keywords: Medical Student Syndrome; Fantasy proneness; Thought suppression

\section{Introduction}

The Medical Student Syndrome (MSS), or the Medical Student Disease (MSD; Woods, Natterson, \& Silverman, 1966) as it is sometimes called, refers to health complaints that are the results of medical expertise rather than genuine pathology. According to Ferguson (1996), MSS "points to the important role played by factual medical knowledge in the interpretation of physiological signs and symptoms" (p. 315). By this view, some medical students would have a tendency to interpret vague bodily symptoms in terms of the latest disease they have learnt about. This tendency would become stronger as medical knowledge grows (Ferguson, 1996). Although both medical teaching staff and medical students are well aware of this phenomenon (Woods et al., 1966), little systematic research has been done on MSS. One exception is the older study of Woods and colleagues (1966) that was carried out to determine the incidence and various manifestations of MSS. These authors noted that $79 \%$ of the respondents in their sample of medical

* Corresponding author. Tel.: + 31-43-388-1963; fax: + 31-43-388-4196.

E-mail address: i.candel@psychology.unimaas.nl (I. Candel).

0191-8869/03/\$ - see front matter (C) 2003 Elsevier Ltd. All rights reserved.

PII: S0191-8869(02)00214-3 
students $(n=33)$ had experienced MSS complaints at some point during their medical education. Interestingly, MSS seems not to be specific for medical students. Hardy and Calhoun (1997) studied worries about mental health in a sample of undergraduates who followed a course in abnormal psychology. Students who planned to major in psychology reported more worries about their psychological health than those planning to major in another discipline. However, it was also the case that the process of learning about various psychiatric diseases decreased students' worries about their mental health, which is quite the opposite of the MSS phenomenon.

The purpose of the current study was two-fold. Given the fact that so far only small-scale studies have been conducted in this domain, our first aim was to examine the prevalence of MSS complaints in a reasonably large sample of medical students. Secondly, we explored whether certain individual difference variables are related to MSS. In previous studies, MSS has been portrayed as a form of hypochondrias (Woods et al., 1966), but factors that may mediate this condition have not been studied so far. On the basis of our earlier work, we speculated that fantasy proneness and thought suppression might be interesting candidates in this respect. Individuals high on fantasy proneness spend a large part of their time fantasizing and daydreaming and they have a strong ability to experience intense sensations. For example, Wilson and Barber (1983) noted that individuals high on fantasy proneness often develop physical symptoms (e.g. pain or thermal sensations) that are directly related to fantasies and thoughts about illness or specific medical conditions. A case in point is pseudocysis (false pregnancy), a phenomenon that seems to have a raised incidence among fantasy prone people.

Habitual thought suppression refers to chronic attempts to dispel certain thoughts from the stream of consciousness (e.g. Wegner, Schneider, Carter, \& White, 1987). There are good reasons to believe that thought suppression is a counterproductive strategy in that it renders the to-besuppressed topic hyperaccessible, an effect that has been dubbed "the white bear effect" (Wegner et al., 1987; see review by Rassin, Merckelbach, \& Muris, 2000). On a related note, suppressing thoughts about pain has been found to delay rather than precipitate pain recovery (Cioffi \& Holloway, 1993). With these considerations in mind, we conducted a survey among medical students. We asked them whether they ever had experienced MSS complaints during their medical study. They also completed self-report measures of fantasy proneness and thought suppression. We speculated that raised scores on these measures would be related to MSS complaints.

\section{Method}

\subsection{Participants}

All third and fourth year medical students at Maastricht University $(n=419)$ received a booklet containing questionnaires and a cover letter that invited them to participate in a study on medical complaints. Participants received a small financial compensation in return for completing the questionnaires. Two-hundred and fifteen participants (158 women) completed and returned the questionnaires (response rate $51 \%$ ). Mean age of the sample was 22 years $(\mathrm{SD}=1,74$; range $=19$ 32 years). About half of the participants ( $n=106 ; 3$ missing) were third year students. 


\subsection{Questionnaires}

Questionnaires included the Creative Experience Questionnaire (CEQ: Merckelbach, Horselenberg, \& Muris, 2001), the White Bear Suppression Inventory (WBSI; Wegner \& Zanakos, 1994), and the Medical Student Syndrome Questionnaire that was specifically developed for the purpose of this study.

The CEQ (Cronbach alpha $=0.73$ ) is a 25 -item self-report instrument that measures fantasy proneness. A sample item is: "Many of my fantasies have a realistic intensity". Items are scaled in the true/false form. The number of yes-answers is summed to yield a total CEQ score, with higher scores indicating higher levels of fantasy proneness. Merckelbach et al. (2001) summarized evidence that supports the reliability and validity of this scale.

The WBSI (Cronbach alpha $=0.88$ ) is a 15 -item questionnaire measuring people's habitual tendency to suppress thoughts. Participants indicate on a 5-point scale the extent to which they agree ( $1=$ strongly disagree; $5=$ strongly agree) with statements such as: "There are things I prefer not to think about". Responses are summed to yield a total score, with higher scores indicating higher levels of thought suppression. Muris, Merckelbach, and Horselenberg (1996) found that WBSI scores are linked to levels of intrusive thinking.

The Medical Student Syndrome Questionnaire began with a case vignette describing a medical student who got concerned about having CNSLD (Chronic Non Specific Lung Disease) after having read about this disorder during a course. Next, respondents were asked whether they had had similar experiences. If so, they were invited to write down the complaints or the disease to which the complaints were related. Next, they were asked to rate on 10 -point scales $(0=$ not at all; $10=$ very much) how serious and frightening they had found their complaints. Finally, they were asked whether a doctor had confirmed the disease.

\section{Results}

\subsection{Medical Student Syndrome}

Thirty-six percent $(n=78)$ of the students reported MSS complaints. Seventeen students $(22 \%)$ consulted a medical specialist. However, in 13 students $(17 \%)$ a disease was diagnosed, indicating that their complaints had an objective medical ground. In our sample then, $30 \%(n=65)$ of the medical students had a history of MSS. MSS data are based on this sample. Third and fourth year students did not differ with regard to MSS frequency $\left[\chi^{2}(1)=0.26 ; P=0.61\right]$. Mean ratings of seriousness and fear of the complaints were $5.08(\mathrm{SD}=1.80)$ and $5.03(\mathrm{SD}=2.56)$, respectively. Seriousness ratings, but not fear ratings, of those who had actually a disease were higher than of those who had not, means being $8.00(\mathrm{SD}=0.82)$ and $5.08(\mathrm{SD}=1.80)$, respectively $[t(76)=-5.73$; $P<0.001]$. The frequency of reported diseases are listed in Table 1. For the purpose of this study, complaints [e.g. Chronic Non Specific Lung Disease (CNSLD), bronchitis] were grouped together in 12 non-overlapping categories. We created one category for non-specified complaints. As can be seen, MSS complaints pertained to a broad variety of diseases. 
Table 1

Reported diseases and their frequency $(n=6.5)$

Diseases Frequency

Pulmonary disease

Coronary and vascular disease

Psychiatric disorder

Gastrointestinal disease

9

Neurological disorder

Cancer

Infectious disease (incl. STD/HIV)

Allergy

Skin disorder

Ear disorder

Diabetes

Gynaecological disorder

Not specified

9

7

6

5

4

1

1

14

Total

a Two participants reported two diseases.

\subsection{Fantasy proneness and thought suppression}

Mean scores on the CEQ and WBSI were analyzed only for participants who answered all items (CEQ: $n=208$; WBSI: $n=213)$ and were $6.05(\mathrm{SD}=3.46)$, and $43.60(\mathrm{SD}=11.53)$, respectively. These scores come close to those that have been previously reported for nonclinincal samples (e.g. Merckelbach, Muris, Horselenberg, \& Stougie, 2000; Muris et al., 1996). The Pearson product-moment correlation between CEQ and WBSI was significant, but modest $(r=0.28 ; P<0.01)$. To evaluate the independent contribution of fantasy proneness, thought suppression, age, and sex, they were entered into a logistic regression analysis as predictors for MSS complaints. Age and sex did not predict presence or absence of MSS complaints (Wald $=0.46 ; P=0.50$ and Wald $=0.44 ; P=0.51$ ), while CEQ scores and WBSI scores were significant and independent predictors of such complaints (Wald $=4.46 ; P<0.05$ and Wald $=4.14 ; P<0.05$, respectively). To explore the robustness of these significances, CEQ and WBSI scores were dichotomised by using median-splits. Next, fantasy proneness, thought suppression, age, and sex were entered as predictors into a logistic regression. This yielded odds ratios (OR's) for CEQ and WBSI of 2.28 (Wald $=6.30 ; P<0.05$ ) and 1.79 (Wald $=2.95 ; P=0.09$ ), respectively. When this analysis was repeated without those participants who did not specify their complaints OR's for CEQ and WBSI were 2.37 (Wald $=6.02 ; P<0.05$ ) and 2.05 (Wald $=3.82 ; P=0.05)$, respectively.

\section{Discussion}

The results of the current study can be summarized as follows. To begin with, about one third of our medical student sample reported a history of MSS. Secondly, MSS complaints pertained to a broad variety of diseases. Third, although both fantasy proneness and thought suppression were 
found to be independent predictors of MSS complaints, fantasy proneness seems to be the most powerful predictor.

Although a substantial percentage of medical students in our study reported a history of MSS, its prevalence was clearly below that reported in the small-scale study of Woods et al. (1966). On the other hand, our finding that MSS complaints pertain to a variety of diseases is in line with Wood et al. (1966) who reported that MSS may involve complaints about organic but also about psychiatric symptoms. In accordance with our expectation, relatively high fantasy proneness scores and a relatively strong habitual tendency to suppress unpleasant thoughts were related to the occurrence of MSS. In their study on fantasy prone individuals, Wilson and Barber (1983) emphasized the intimate association between vivid fantasies and physical concomitants. A surprisingly large number of fantasy prone individuals interviewed by these authors reported that they had experienced false pregnancies (pseudocyesis) and/or other illnesses that developed on the basis of a fantasy about being ill. We do not want to argue that the students who reported MSS complaints in the current study were fantasy prone individuals. Our point is that raised fantasy proneness levels may make undergraduates vulnerable when they relate newly acquired technical knowledge about a disease to vague bodily symptoms they experience. Further anecdotal evidence for this comes from an informal study that we conducted among bogus patients who volunteer to role-play certain diseases during practical courses in medical school. In that study, three out of 60 bogus patients said that they were familiar with the phenomenon of developing genuine complaints as a result of role-playing. These three bogus patients had raised CEQ scores $(M=11,33, \mathrm{SD}=4.51)$ relative to those who were not familiar with this phenomenon $(M=6.49 ; \mathrm{SD}=4.05)$. Thus, it is conceivable that those who score relatively high on fantasy proneness tend to develop worse case scenario-interpretations of bodily sensations. On a related note, a relatively strong tendency to suppress worries about the meaning of bodily experiences may radicalise such worries through the ironic white bear-effect (e.g. Cioffi \& Holloway, 1993), especially if these worries are based on sophisticated knowledge about pathology.

An obvious limitation of the current study is that it was correlational in nature. Thus, we cannot be sure whether and to what extent fantasy proneness and habitual thought suppression are causal antecedents of MSS complaints. Clearly, prospective studies are required to resolve the causality issue. Such studies would bear relevance not only to the phenomenon of MSS, but also to other situations that involve communication of medical expertise. As an example, health promotion programs often aim at informing large groups of people about certain diseases. Perhaps, such information may have a paradoxical effect in individuals scoring high on fantasy proneness and/or thought suppression. Another example is provided by research on screening instruments for malingering. This research is often based on naive undergraduates who are instructed to feign a certain disorder. Meanwhile, there are indications that malingering a disorder and believing that one has a disorder form a continuum (Christianson \& Bylin, 1999). If this is true, individuals high on fantasy proneness and/or thought suppression might be particularly talented to serve as instructed malingerers in experimental research on malingering.

\section{References}

Christianson, S., \& Bylin, S. (1999). Does simulating amnesia mediate genuine forgetting for a crime event? Applied Cognitive Psychology 13, 495-511. 
Cioffi, D., \& Holloway, J. (1993). Delayed costs of suppressing pain. Journal of Personality and Social Psychology, 64, 274-282.

Ferguson, E. (1996). Hypochondriacal concerns: the role of raw and calibrated medical knowledge. Psychology, Health \& Medicine, $1,315-318$.

Hardy, M. S., \& Calhoun, L. G. (1997). Psychological distress and the "Medical Student Syndrome" in abnormal psychology students. Teaching of Psychology, 24, 192-193.

Merckelbach, H., Horselenberg, R., \& Muris, P. (2001). The Creative Experience Questionnaire (CEQ): a brief selfreport measure of fantasy proneness. Personality and Individual Differences, 31, 987-995.

Merckelbach, H., Muris, P., Horselenberg, H., \& Stougie, S. (2000). Dissociation, reality monitoring, and response bias. Personality and Individual Differences, 28, 49-58.

Muris, P., Merckelbach, H., \& Horselenberg, R. (1996). Individual differences in thought suppression. The White Bear Suppression Inventory: factor structure, reliability, validity and correlates. Behaviour Research and Therapy, 34, 501513.

Rassin, E., Merckelbach, H., \& Muris, P. (2000). Paradoxical and less paradoxical effects of thought suppression: a critical review. Clinical Psychology Review, 20, 973-995.

Wegner, D. M., Schneider, D. J., Carter, S. R., \& White, T. L. (1987). Paradoxical effects of thoughts suppression. Journal of Personality and Social Psychology, 53, 5-13.

Wegner, D. M., \& Zanakos, S. (1994). Chronic thought suppression. Journal of Personality, 62, 615-640.

Wilson, S. C., \& Barber, T. X. (1983). Fantasy-prone personality: implications for understanding imagery, hypnosis, and parapsychological phenomena. In A. A. Sheikh (Ed.), Imagery: current theory, research, and application (pp. 340387). New York: Wiley.

Woods, S. M., Natterson, J., \& Silverman, J. (1966). Medical students' disease: Hypochondriasis in medical education. Journal of Medical Education, 41, 785-790. 